\title{
KEMAMPUAN PROSES DAN KARAKTERISTIK VULKANISASI CAMPURAN NBR/EPDM
}

\author{
PROCESSABILITY AND VULCANIZATION CHARACTERISTICS OF NBR/EPDM BLEND
}

\author{
Hesty Eka Mayasari ${ }^{1)}$, Ike Setyorini ${ }^{1)}$ dan Noor Maryam Setyadewi ${ }^{1)}$ \\ ${ }^{1)}$ Balai Besar Kulit, Karet, dan Plastik \\ Jl. Sokonandi No. 9 Yogyakarta, 55166, Indonesia \\ e-mail: hestyeka@kemenperin.go.id
}

Diterima: 6 Februari 2018; Direvisi : 23 Februari 2018 - 20 Juni 2018; Disetujui: 28 Juni 2018

\begin{abstract}
ABSTRAK
Pencampuran dua karet atau lebih dapat menghasilkan sifat produk yang unggul. Penelitian ini mempelajari tentang kemampuan proses dan karakteristik pematangan dari campuran NBR/EPDM. Pada penelitian ini digunakan beberapa jenis kompatibiliser, yaitu metil-metakrilat-butadiene-stirene (MBS), montmorillonite, dan silika. Kompatibiliser digunakan untuk mendapatkan kompon yang homogen. Kompon NBR/EPDM dibuat dengan menggunakan two-roll mill. Viskositas mooney, reologi, dan kinetika pematangan dipelajari dengan menggunakan mooney viscometer dan rheometer. Dari penelitian yang telah dilakukan, diketahui bahwa campuran NBR/EPDM menghasilkan kompon dengan kemampuan proses, waktu pematangan, serta indeks kecepatan reaksi yang lebih baik dari kompon NBR dan kompon EPDM secara terpisah. Montmorillonite sebagai kompatibiliser menghasilkan kompon yang memiliki kemampuan proses serta memberikan indeks kecepatan reaksi yang lebih baik dibandingkan dengan MBS dan silika. Montmorillonite dapat menjadi kompatibiliser yang sesuai untuk campuran NBR/EPDM.
\end{abstract}

Kata kunci: NBR/EPDM, MBS, montmorillonite, silika, kompatibiliser

\section{ABSTRACT}

Blending of two rubbers can produce superior product properties. This study examines the process and cure characteristics of the NBR/EPDM blend. This study used several types of compatibilizer, i.e. methylmethacrylate-butadiene-stirene (MBS), montmorillonite, and silica. Compatibilizer is used to get the homogeneous blend. NBR/EPDM compounds were done by two-roll mill. The mooney viscosity, rheology, and cure kinetics were studied with mooney viscometer and rheometer. It is known that the NBR/EPDM blends produce the compound with the process ability, curing time, and cure rate index better than NBR compound and EPDM compound separately. Montmorillonite as the compatibilizer produces compound with the process ability and cure rate index better than MBS and silica. Montmorillonite can be used as appropriate compatibilizer for the NBR/EPDM blend.

Keywords: NBR/EPDM, MBS, montmorillonite, silica, compatibilizer

\section{PENDAHULUAN}

Karet merupakan polimer yang memiliki banyak kegunaan di kehidupan sehari-hari. Kebutuhan akan produk karet semakin lama semakin meningkat dan bervariasi seiring dengan bertambahnya kebutuhan manusia. Saat ini, penelitian banyak dilakukan mengenai pencampuran antar karet, baik karet alam dengan karet alam maupun karet alam dengan karet sintetis. Pencampuran dua buah karet dapat meningkatkan kualitas produk dan mengimprovisasi kekurangan dari masingmasing karet yang digunakan. Proses pencampuran karet merupakan hal menarik karena banyak hal yang perlu diperhatikan agar tercapainya produk yang diinginkan. Beberapa hal yang menyebabkan campuran tidak kompatibel diantaranya perbedaan polaritas, kejenuhan, dan kelarutan. Beberapa cara untuk mendapatkan campuran karet yang kompatibel diantaranya dengan penambahan kompatibiliser (Tawfik \& El, 2014) ataupun dengan modifikasi teknik blending (Indrajati \& Sholeh, 2014).

Dalam penelitian ini, dipelajari pencampuran antar karet sintetis yaitu karet NBR (Nitrile butadiene rubber) dan EPDM (Ethylene propylene diene monomer rubber). Karet NBR adalah kopolimer dari akrilonitril dan butadiena yang bersifat polar dan tidak jenuh. 
Kepolaran dari NBR ini ditentukan oleh besarnya kadar akrilonitril dalam NBR. Semakin besar kadar ACN, semakin tahan terhadap pelarut hidrokarbon (Kantala et al., 2009). NBR banyak digunakan pada industri otomotif karena ketahannya terhadap minyak yang baik. Namun, karet NBR mudah terdeteorisasi ozon dan tidak tahan terhadap pelarut polar (Jovanović et al., 2009). EPDM adalah karet nonpolar dan memiliki ketahanan ozon yang baik karena memiliki ikatan jenuh pada strukturnya (Ning et al., 2014). EPDM memiliki ketahanan terhadap pelarut polar dan ketahanan terhadap panas yang baik (Yi et al., 2014). EPDM banyak digunakan di industri kimia dan sebagai insulator (Jovanovic et al., 2013).

Dalam penelitian ini akan dilakukan pencampuran NBR/EPDM dengan penggunaan beberapa kompatibiliser, diantaranya dengan MBS (methyl methacrylate-butadiene-styrene),

montmorillonite, dan silika. MBS sebelumnya digunakan oleh Arayapranee et al. dan mendapatkan hasil bahwa bahwa MBS dapat meningkatkan kompatibilitas NR/EPDM (Arayapranee \& Rempel, 2007). MBS dikenal dapat mengimprovisasi ketahanan impak pada polimer. MBS mengandung polimer karet pada susunan elastomernya yaitu styrene-butadiene rubber (SBR) sehingga dapat meningkatkan sifat mekanik polimer (Ren et al., 2014; Liu et al., 2014; Zhou et al., 2012). MBS juga banyak digunakan sebagai kompatibiliser baik untuk plastik (Moolsin \& Saksayamkul, 2016; Mousavi \& Amraei, 2015; Liu et al., 2014). Montmorillonite (MMT) adalah salah satu mineral tanah liat alami yang memiliki luas permukaan yang besar. Beberapa penelitian menggunakan MMT sebagai kompatibiliser, dan didapatkan hasil bahwa MMT dapat meningkatkan ketahanan termal, ketahanan terhadap api dan memperbaiki sifat mekanik pada EPDM (Yi et al., 2014), NBR/SBR (Tawfik \& El, 2014), EPDM/silicone (Vijayalekshmi \& M, 2013), NBR (Rajasekar et al., 2009). Sedangkan silika merupakan salah satu bahan pengisi yang banyak digunakan untuk produk karet yang berwarna. Namun, silika juga dapat memberikan pengaruh yang baik sebagai kompatibiliser yang ditunjukkan pada penelitian yang dilakukan oleh Kantala et al. pada campuran NR/NBR (Kantala et al., 2009).

Pencampuran NBR/EPDM ini diharapakan dapat menghasilkan produk dengan kualitas superior dan mengurangi kelemahan pada masing-masing karet. Diharapkan campuran NBR/EPDM dapat menghasilkan produk yang memiliki ketahanan terhadap oli dan panas yang baik dan dapat diaplikasikan di industri otomotif, selang, dan belt conveyor. Penelitian mengenai pencampuran NBR/EPDM telah banyak dilakukan, terutama mengenai blending rasio dan bahan pengisi (Al-gahtani, 2011; Samarz et al., 2013; Jovanovic et al., 2013). Namun, penelitian mengenai jenis kompatibiliser yang cocok untuk campuran ini belum banyak dilakukan. Dalam penelitian ini dilakukan blending NBR/EPDM baik tanpa kompatibiliser maupun dengan menggunakan beberapa kompatibiliser. Kompatibiliser yang digunakan dalam penelitian ini adalah metil-metakrilat-butadiene-stirene (MBS), montmorillonite, dan silika. Dengan diketahuinya perbedaan hasil penggunaan kompatibiliser maupun tanpa kompatibiliser serta diketahuinya jenis kompatibiliser terbaik, maka dapat diketahui formulasi yang tepat dalam pencampuran NBR/EPDM.

\section{BAHAN DAN METODE}

\section{Bahan}

Bahan-bahan yang digunakan dalam penelitian ini adalah NBR (Krynac $4975 \mathrm{~F}$ dengan kadar ACN 48,5 $\pm 1,5 \%$,), EPDM (Keltan 4551 A dengan kadar ENB 8,7\%). Bahan aditif yang digunakan adalah zinc oxide $(\mathrm{ZnO})$ Indoxide dan asam stearat Aflux $42 \mathrm{M}$ ex Rhein Chemie sebagai aktivator, carbon black jenis N330 High Abrassion Furnace (HAF) dan N774 Semi Reinforcing Furnace (SRF) (OCl, Korea) sebagai filler, parafinic oil dari Indrasari, parafin wax Antilux 654 A sebagai anti oksidan, TMQ Kemai sebagai antioksidan, 6PPD Starchem sebagai anti ozonan, 2,2'dithiobis(benzothiazole) (MBTS) Kemai, 
$\mathrm{N}$-cyclohexyl-benzothiazylsulphenamide (CBS) Kemai sebagai akselerator, methyl methacrylate-butadiene-styrene (MBS) ZB-521 ZB-32 (Huaxing), montmorillonite (Sigma Aldrch), dan Silika (Zeosil 175P, Rhodia Silica Qingdao) sebagai kompatibiliser, PEG (PEG 4000 Korea), serta sulfur Miwon sebagai bahan pemvulkanisasi.

\section{Peralatan}

Alat yang digunakan dalam penelitian ini meliputi two-roll mill, hydraulic press, mooney viscometer, rheometer MDR
Gotech 3000 A, tensile strength tester merk Kao Tieh, dan durometer shore $\mathrm{A}$.

\section{Metode Penelitian}

NBR dan EPDM serta bahan tambahan lainnya ditimbang sesuai formulasi, selanjutnya digiling dengan tworoll mill dengan suhu $40-50^{\circ} \mathrm{C}$. Kompon yang diperoleh dikondisikan pada suhu ruang selama 24 jam. Setelah itu dilakukan uji dengan rheometer. Selanjutnya kompon divulkanisasi sesuai waktu pada rheometer. Formulasi penelitian ditunjukkan pada Tabel 1 .

Tabel 1. Formulasi komposit NBR/EPDM

\begin{tabular}{lcccccc}
\hline \multirow{2}{*}{ Jenis bahan } & \multicolumn{7}{c}{ Jumlah bahan, phr } \\
\cline { 2 - 7 } & $\mathbf{N}_{10} \mathbf{E}_{\mathbf{0}}$ & $\mathbf{N}_{\mathbf{0}} \mathbf{E}_{10}$ & $\mathbf{N}_{5} \mathbf{E}_{5}$ & $\mathbf{N}_{5} \mathbf{E}_{5} \mathbf{M}$ & $\mathbf{N}_{5} \mathbf{E}_{5} \mathbf{M M T}$ & $\mathbf{N}_{5} \mathbf{E}_{5} \mathbf{S}$ \\
\hline NBR & 100 & 0 & 50 & 50 & 50 & 50 \\
EPDM & 0 & 100 & 50 & 50 & 50 & 50 \\
Zinc Oksida (ZnO) & 5 & 5 & 5 & 5 & 5 & 5 \\
Asam stearat & 1 & 1 & 1 & 1 & 1 & 1 \\
HAF CB N330 & 30 & 30 & 30 & 30 & 30 & 30 \\
SRF CB N774 & 30 & 30 & 30 & 30 & 30 & 30 \\
MBS & 0 & 0 & 0 & 2.5 & 0 & 0 \\
Montmorillonite & 0 & 0 & 0 & 0 & 2.5 & 0 \\
Silica (zeosil) & 0 & 0 & 0 & 0 & 0 & 2.5 \\
PEG & 0 & 0 & 0 & 0 & 0 & 0.1 \\
Paraffinic Oil & 10 & 10 & 10 & 10 & 10 & 10 \\
Paraffinic Wax & 0.5 & 0.5 & 0.5 & 0.5 & 0.5 & 0.5 \\
6 PPD & 5 & 5 & 5 & 5 & 5 & 5 \\
MBTS & 1.5 & 1.5 & 1.5 & 1.5 & 1.5 & 1.5 \\
CBS & 0.5 & 0.5 & 0.5 & 0.5 & 0.5 & 0.5 \\
Sulphur & 1.5 & 1.5 & 1.5 & 1.5 & 1.5 & 1.5 \\
\hline
\end{tabular}

\section{Viskositas Mooney NBR/EPDM (ML1+4, $\left.100^{\circ} \mathrm{C}\right)$}

Viskositas mooney $\mathrm{ML}(1+4)$, diukur dengan menggunakan MonTech Mooney Viscometer MV 3000 pada $100^{\circ} \mathrm{C}$ dengan kecepatan rotor 2 rpm $(0.21$ putaran/detik). Kondisi ML (1+4) diartikan 1 menit pre-heating dan uji selama 4 menit.

\section{Reologi campuran NBR/EPDM}

Waktu scorch $\left(\mathrm{ts}_{2}\right)$, waktu pemasakan optimum $\left(\mathrm{t}_{90}\right)$, kecepatan reaksi, torsi viskos (S") and elastis (S') didapat dari pengujian dengan menggunakan Moving
Die Rheometer Gotech M-3000A. Sampel diuji pada suhu $150,160,170$ and $180^{\circ} \mathrm{C}$.

Dari hasil rheometer, dapat dihitung indeks kecepatan pematangan (CRI) dengan persamaan berikut:

$$
\mathrm{CRI}=\frac{100}{\left(t_{90}-t s_{2}\right)}
$$

Dari hasil rheometer juga dapat dipelajari kinetika pematangannya, untuk kemudian didapatkan konstanta kecepatan reaksi. Kinetika pematangan dapat dihitung menggunakan model kinetika untuk 
memprediksi waktu pematangan optimum. Perhitungan konstanta kecepatan reaksi dilakukan sepertipenelitian sebelumnya (Semsarzadeh et al., 2005; Yuniari et al., 2016). Reaksi kimia secara umum dapat dimodelkan dalam persamaan diferensial seperti pada persamaan (2)

$$
\frac{d x}{d t}=k f(x)
$$

Dimana persamaan kimia secara umum dapat ditulis sebagai berikut:

$$
k=A \exp \left(-\frac{E}{R T}\right)
$$

Derajat kematangan atau konversi $(\alpha)$ didefinisikan oleh persamaan (1)

$$
\ln \frac{\left(M_{H}-M_{L}\right)}{\left(M_{H}-M_{t}\right)}=k t
$$

Dengan memplotkan $\ln \left(M_{H}-M_{t}\right)$ dan $t$, didapatkan garis lurus reaksi pematangan mengikuti orde pertama dan didapatkan nilai konstanta kecepatan reaksi, $k$.

\section{HASIL DAN PEMBAHASAN}

\section{a. Viskositas Mooney}

Viskositas mooney menunjukkan kemampuan proses dari kompon yang menunjukkan kemampuan alir kompon. Semakin tinggi viskositas menunjukkan kemampuan alir yang kurang baik sehingga semakin susah suatu kompon untuk diproses. Hal ini kurang disukai di industri karena membutuhkan tenaga yang besar untuk memprosesnya. Namun, kompon dengan viskositas yang tinggi memiliki sifat mekanik yang lebih baik dari kompon dengan viskositas mooney yang rendah (Mayasari et al., 2017).

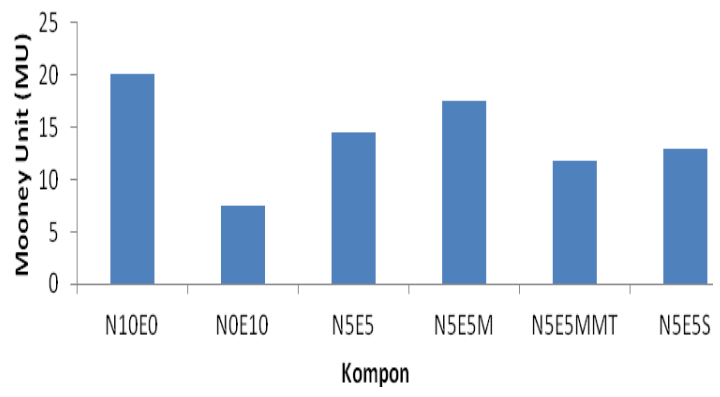

Gambar 1. Viskositas mooney (ML 1+4) campuran NBR/EPDM
Dari hasil pengujian, kompon EPDM (NOE10) memiliki viskositas mooney yang paling rendah dan kompon NBR (N10E0) memiliki viskositas mooney tertinggi. Hal ini menunjukkan bahwa EPDM memiliki laju alir yang lebih baik dari NBR, sehingga lebih mudah diproses dan dicetak. Kompon campuran NBR/EPDM menunjukkan viskositas mooney yang berada diantara viskositas mooney kompon NBR dan kompon EPDM secara terpisah. Hal ini menunjukkan bahwa laju alir kompon campuran NBR/EPDM lebih baik jika dibandingkan dengan kompon NBR dan sifat mekaniknya juga lebih baik daripada kompon EPDM.

Montmorillonite memberikan viskositas mooney lebih rendah (11.735 $\mathrm{MU})$ dibandingkan dengan kompatibiliser lainnya, sedangkan MBS memberikan viskositas mooney tertinggi. Dari hasil uji viskositas mooney ini, diketahui bahwa montmorillonite ini memberi pengaruh yang baik dalam laju alir kompon NBR/EPDM. Dimungkinkan kompatibiliser montmorillonite terdispersi merata pada molekul karet sehingga membuat kompon mudah mengalir.

\section{b. Reologi dan karakteristik dinamik}

Pengujian reologi kompon dilakukan dengan rheometer. Dari hasil pengujian dari rheometer didapatkan waktu scorch

$\left(\mathrm{ts}_{2}\right)$ dan waktu optimum $\left(\mathrm{tc}_{90}\right)$ yang ditunjukkan pada Tabel 2. Waktu scorch adalah indikator waktu aman untuk kompon. Waktu scorch merupakan batas waktu aman ketika kompon masih dapat diproses karena bersifat plastis. Semakin tinggi waktu scorch, semakin baik kompon tersebut karena memiliki waktu simpan yang lebih lama. Setelah melewati waktu scorch, akan terjadi reaksi kimia dan terbentuk ikatan silang antara molekul karet dan bahan aditifnya. Pembentukan ikatan silang ini akan berlangsung hingga tc $_{90}$ (Yuniari et al., 2016). Waktu optimum (tc 90 ) adalah waktu yang dibutuhkan kompon hingga masak. Dalam proses pembentukan ikatan silang, dibutuhkan energi panas, sehingga waktu optimum 
$\left(\mathrm{tc}_{90}\right)$ yang lebih singkat lebih disukai untuk mengurangi biaya produksi.

Tabel 2. Waktu scorch dan waktu optimum kompon NBR/EPDM

\begin{tabular}{|c|c|c|c|c|c|c|c|c|}
\hline \multirow{2}{*}{ Kompon } & \multicolumn{4}{|c|}{$\mathrm{ts}_{2}$, detik } & \multicolumn{4}{|c|}{ tc $_{90}$, detik } \\
\hline & $150^{\circ} \mathrm{C}$ & $160^{\circ} \mathrm{C}$ & $170^{\circ} \mathrm{C}$ & $180^{\circ} \mathrm{C}$ & $150^{\circ} \mathrm{C}$ & $160^{\circ} \mathrm{C}$ & $170^{\circ} \mathrm{C}$ & $180^{\circ} \mathrm{C}$ \\
\hline$N_{10} E_{0}$ & 46 & 28 & 16.5 & 10.5 & 460.5 & 504.5 & 402.5 & 272.5 \\
\hline $\mathrm{N}_{0} \mathrm{E}_{10}$ & 460.5 & 504.5 & 402.5 & 272.5 & 2822.5 & 2339.5 & 1848.5 & 1089.5 \\
\hline$N_{5} E_{5}$ & 60.5 & 15 & 22 & 17.5 & 948 & 444.5 & 249.5 & 129.5 \\
\hline $\mathrm{N}_{5} \mathrm{E}_{5} \mathrm{M}$ & 57 & 4.5 & 23.5 & 18 & 1161.5 & 520.5 & 259.5 & 168 \\
\hline $\mathrm{N}_{5} \mathrm{E}_{5} \mathrm{MMT}$ & 59.5 & 7.5 & 26 & 17 & 1059.5 & 434.5 & 263 & 128 \\
\hline $\mathrm{N}_{5} \mathrm{E}_{5} \mathrm{~S}$ & 59 & 31 & 25 & 17.5 & 1069.5 & 610 & 314 & 144.5 \\
\hline
\end{tabular}

Dari hasil pengujian diketahui bahwa secara umum kompon NBR (N10E0) memberikan waktu scorch time dan waktu optimum pemasakan yang paling rendah. Sedangkan kompon EPDM (NOE10) memberikan waktu aman dan waktu pemasakan optimum yang paling tinggi. Sedangkan campuran NBR/EPDM memberikan waktu aman dan waktu pematangan diantara keduanya, sehingga pencampuran kedua karet ini dapat memberikan waktu aman yang lebih lama dan juga waktu pemasakan optimum yang lebih cepat $(948 ; 444.5 ; 249.5 ; 129.5$ detik pada 150, 160, 170, dan $180^{\circ} \mathrm{C}$ ). Sedangkan pengaruh kompatibiliser tidak memberikan pengaruh yang signifikan pada waktu scorch dan waktu pemasakan optimum.

Suhu vulkanisasi memberikan pengaruh pada scorch time dan waktu optimum pemasakan. Semakin tinggi suhu vulkanisasi, secara umum semakin cepat juga waktu scorch dan waktu pemasakan optimum. Hal ini dikarenakan panas dapat meningkatkan laju reaksi, sehingga reaksi antara molekul karet dan bahan aditifnya berlangsung lebih cepat (Yuniari et al., 2017).

Dari persamaan (1) dapat diketahui $\mathrm{CRI}$ (cure rate index) suatu kompon yang ditunjukkan pada Tabel 3. CRI yang tinggi menunjukkan tingginya kecepatan reaksi. Semakin tinggi suhu vulkanisasi menghasilkan CRI yang semakin tinggi. Hal ini dikarenakan panas dapat membuat partikel karet dan bahan aditif bergerak semakin cepat, sehingga tumbukan antar molekul karet terjadi lebih sering, maka laju reaksi akan meningkat. Campuran NBR/EPDM tanpa kompatibiliser memberikan nilai $\mathrm{CRI}$ yang secara umum lebih besar dari kompon NBR dan kompon EPDM secara terpisah $(0.113 ; 0.233$; $0.440 ; 0.893$ detik $^{-1}$ pada 150, 160, 170, dan $180^{\circ} \mathrm{C}$ ) yang menunjukkan bahwa reaksi vulkanisasi campuran NBR/EPDM lebih cepat dari kompon NBR dan kompon EPDM secara terpisah. Montmorillonite sebagai kompatibiliser memberikan laju reaksi yang tinggi yang menunjukkan bahwa reaksi vulkanisasi terjadi lebih cepat. Hal ini sesuai dengan waktu pemasakan optimum yang lebih cepat dari kompon lainnya $(1059,5 ; 434.5$; 263; 128 detik pada 150, 160, 170, dan $\left.180^{\circ} \mathrm{C}\right)$.

Tabel 3. CRI kompon NBR/EPDM

\begin{tabular}{lrrrr}
\hline \multirow{2}{*}{ Kompon } & \multicolumn{4}{c}{$\mathrm{CRI}\left(\mathrm{detik}^{-1}\right)$} \\
& $150^{\circ} \mathrm{C}$ & $160^{\circ} \mathrm{C}$ & $170^{\circ} \mathrm{C}$ & $180^{\circ} \mathrm{C}$ \\
\hline $\mathbf{N}_{10} \mathrm{E}_{0}$ & 0.241 & 0.210 & 0.259 & 0.382 \\
$\mathbf{N}_{0} \mathrm{E}_{10}$ & 0.042 & 0.054 & 0.069 & 0.122 \\
$\mathbf{N}_{5} \mathbf{E}_{5}$ & 0.113 & 0.233 & 0.440 & 0.893 \\
$\mathbf{N}_{5} \mathbf{E}_{5} \mathbf{M}$ & 0.091 & 0.194 & 0.424 & 0.667 \\
$\mathbf{N}_{5} \mathbf{E}_{5} \mathrm{MMT}$ & 0.100 & 0.234 & 0.422 & 0.901 \\
$\mathbf{N}_{5} \mathbf{E}_{5} \mathbf{S}$ & 0.099 & 0.173 & 0.346 & 0.787 \\
\hline
\end{tabular}


Tabel 4. Karakteristik dinamik kompon NBR/EPDM

\begin{tabular}{|c|c|c|c|c|c|c|c|c|}
\hline $\begin{array}{c}\text { Suhu } \\
\text { vulkanisasi }\end{array}$ & Kompon & $\begin{array}{c}\text { S'ML } \\
\text { kgf.cm }\end{array}$ & $\begin{array}{c}\text { S'MH } \\
\text { kgf.cm }\end{array}$ & $\begin{array}{l}\text { S"ML } \\
\text { kgf.cm }\end{array}$ & $\begin{array}{l}\text { S"MH } \\
\text { kgf.cm }\end{array}$ & $\begin{array}{l}\tan \delta \\
\text { S"ML } \\
\end{array}$ & $\begin{array}{l}\tan \delta \\
\text { S"MH }\end{array}$ & $\begin{array}{c}\text { delta torsi } \\
\text { kgf.cm }\end{array}$ \\
\hline \multirow{6}{*}{$150^{\circ} \mathrm{C}$} & $\mathrm{N}_{10} \mathrm{E}_{0}$ & 4.22 & 50.42 & 4.14 & 10.98 & 0.98 & 0.22 & 46.2 \\
\hline & $\mathrm{N}_{0} \mathrm{E}_{10}$ & 5.61 & 34.27 & 5.46 & 9.48 & 0.97 & 0.28 & 28.66 \\
\hline & $\mathrm{N}_{5} \mathrm{E}_{5}$ & 4.09 & 42.97 & 4.1 & 10.78 & 1.00 & 0.25 & 38.88 \\
\hline & $\mathrm{N}_{5} \mathrm{E}_{5} \mathrm{M}$ & 4.46 & 43.09 & 4.43 & 12.14 & 0.99 & 0.28 & 38.63 \\
\hline & $\mathrm{N}_{5} \mathrm{E}_{5} \mathrm{MMT}$ & 4.55 & 40.39 & 4.38 & 11.6 & 0.96 & 0.29 & 35.84 \\
\hline & $\mathrm{N}_{5} \mathrm{E}_{5} \mathrm{~S}$ & 4.27 & 37.65 & 4.24 & 10.92 & 0.99 & 0.29 & 33.38 \\
\hline \multirow{6}{*}{$160^{\circ} \mathrm{C}$} & $\mathrm{N}_{10} \mathrm{E}_{0}$ & 3.99 & 59.21 & 3.9 & 12.55 & 0.98 & 0.21 & 55.22 \\
\hline & $\mathrm{N}_{0} \mathrm{E}_{10}$ & 5.66 & 36.44 & 5.26 & 10.64 & 0.93 & 0.29 & 30.78 \\
\hline & $\mathrm{N}_{5} \mathrm{E}_{5}$ & 4.05 & 41.92 & 4.01 & 10.45 & 0.99 & 0.25 & 37.87 \\
\hline & $\mathrm{N}_{5} \mathrm{E}_{5} \mathrm{M}$ & 4.29 & 39.51 & 4.15 & 11.59 & 0.97 & 0.29 & 35.22 \\
\hline & $\mathrm{N}_{5} \mathrm{E}_{5} \mathrm{MMT}$ & 4.27 & 38.09 & 4.16 & 11.45 & 0.97 & 0.30 & 33.82 \\
\hline & $\mathrm{N}_{5} \mathrm{E}_{5} \mathrm{~S}$ & 4.06 & 40.46 & 4 & 11.78 & 0.99 & 0.29 & 36.4 \\
\hline \multirow{6}{*}{$170^{\circ} \mathrm{C}$} & $\mathrm{N}_{10} \mathrm{E}_{0}$ & 3.52 & 55.11 & 3.58 & 11.98 & 1.02 & 0.22 & 51.59 \\
\hline & $\mathrm{N}_{0} \mathrm{E}_{10}$ & 5.25 & 44.01 & 5.1 & 10.18 & 0.97 & 0.23 & 38.76 \\
\hline & $\mathrm{N}_{5} \mathrm{E}_{5}$ & 3.76 & 40.68 & 3.79 & 9.41 & 1.01 & 0.23 & 36.92 \\
\hline & $\mathrm{N}_{5} \mathrm{E}_{5} \mathrm{M}$ & 4.00 & 37.36 & 3.93 & 11.44 & 0.98 & 0.31 & 33.36 \\
\hline & $\mathrm{N}_{5} \mathrm{E}_{5} \mathrm{MMT}$ & 3.97 & 36.25 & 3.95 & 11.07 & 0.99 & 0.31 & 32.28 \\
\hline & $\mathrm{N}_{5} \mathrm{E}_{5} \mathrm{~S}$ & 3.67 & 37.5 & 3.71 & 11.54 & 1.01 & 0.31 & 33.83 \\
\hline \multirow{6}{*}{$180^{\circ} \mathrm{C}$} & $N_{10} E_{0}$ & 3.54 & 51.76 & 3.63 & 12.3 & 1.03 & 0.24 & 48.22 \\
\hline & $\mathrm{N}_{0} \mathrm{E}_{10}$ & 5.4 & 45.58 & 5.02 & 10.26 & 0.93 & 0.23 & 40.18 \\
\hline & $\mathrm{N}_{5} \mathrm{E}_{5}$ & 3.52 & 37.1 & 3.6 & 9.57 & 1.02 & 0.26 & 33.58 \\
\hline & $\mathrm{N}_{5} \mathrm{E}_{5} \mathrm{M}$ & 3.8 & 35.13 & 3.71 & 10.8 & 0.98 & 0.31 & 31.33 \\
\hline & $\mathrm{N}_{5} \mathrm{E}_{5} \mathrm{MMT}$ & 4.26 & 34.72 & 4.06 & 10.29 & 0.95 & 0.30 & 30.46 \\
\hline & $\mathrm{N}_{5} \mathrm{E}_{5} \mathrm{~S}$ & 3.54 & 34.27 & 3.63 & 12.3 & 1.03 & 0.36 & 30.73 \\
\hline
\end{tabular}

Tabel 4 menunjukkan karakteristik dinamik dari kompon NBR/EPDM. Data karakteristik ini didapat dari pengujian dengan menggunakan rheometer, yang menunjukkan $\mathrm{mH}$ (torsi maksimum) dan $\mathrm{mL}$ (torsi minimum). Karet merupakan material yang memiliki elemen viskos (S") dan elemen elastis (S') sehingga disebut bersifat viskoelatis. Dari Tabel 4 diketahui bahwa kompon EPDM memberikan S'ML yang tertinggi. Torsi elastis minimun (S'ML) berhubungan dengan viskositas dan kemampuan proses kompon (Jovanovic et al., 2013; Kinasih \& Fathurrohman, 2016). Hal ini menunjukkan bahwa kompon EPDM memberikan viskositas dan kemampuan proses terbaik, sesuai dengan hasil uji viskositas mooney. Sedangkan torsi elastis maksimum (S'MH) menunjukkan 
ikatan silang pada proses vulkanisasi. Dari Tabel 4 diketahui bahwa kompon NBR memberikan S'MH tertinggi, demikian pula dengan selisih torsi (S'MH-S'ML). Sedangkan campuran NBR/EPDM tanpa kompatibiliser memberikan selisih torsi sedikit lebih tinggi dibandingkan campuran NBR/EPDM dengan kompatibiliser. Selisih torsi merepresentasikan banyaknya ikatan silang yang terjadi dan berkaitan dengan modulus geser pada kompon (Jovanović et al., 2009).

Dari hasil uji rheometer juga dapat diketahui karakteristik damping dari kompon. Karakteristik damping adalah rasio dari elemen viskos dan elastis (S"'S'). Hal ini penting untuk mengetahui sifat kompon yang berhubungan dengan pencetakan. Tan $\delta(\mathrm{ML})$ menunjukkan karakteristik damping pada kompon dan $\tan \delta(\mathrm{MH})$ menunjukkan karakteristik damping pada vulkanisat. Dari Tabel 4 diketahui bahwa faktor damping ( $\tan \delta$ $\mathrm{MH}$ ) berbanding terbalik dengan jumlah ikatan silang. Ikatan silang yang tinggi menunjukkan bahwa vulkanisat banyak didominasi oleh elemen elastis (Nabil et al., 2013; Indrajati \& Sholeh, 2014).

c. Kinetika vulkanisasi

Kinetika vulkanisasi dapat dipelajari dari data rheometer. Dari persamaan (4) didapatkan grafik plot yang ditunjukkan pada Gambar2 sehingga dapat dilakukan perhitungan kinetika vulkanisasi yang disajikan pada Tabel 5. Suhu vulkanisasi yang semakin tinggi memberikan konstanta kecepatan reaksi yang juga semakin tinggi. Hal ini dikarenakan panas dapat membuat partikel karet dan bahan aditif bergerak semakin cepat, sehingga tumbukan antar molekul terjadi lebih sering dan laju reaksi meningkat. Konstanta kecepatan reaksi tertinggi diberikan oleh montmorillonite, yang menunjukkan bahwa kompatibiliser dapat meningkatkan kecepatan reaksi. Hal ini juga sesuai dengan perhitungan $\mathrm{CRI}$ yang menyatakan bahwa montmorillonite menghasilkan indeks kecepatan pematangan tertinggi. Konstanta kecepatan reaksi merepresentasikan indeks kecepatan pematangan.

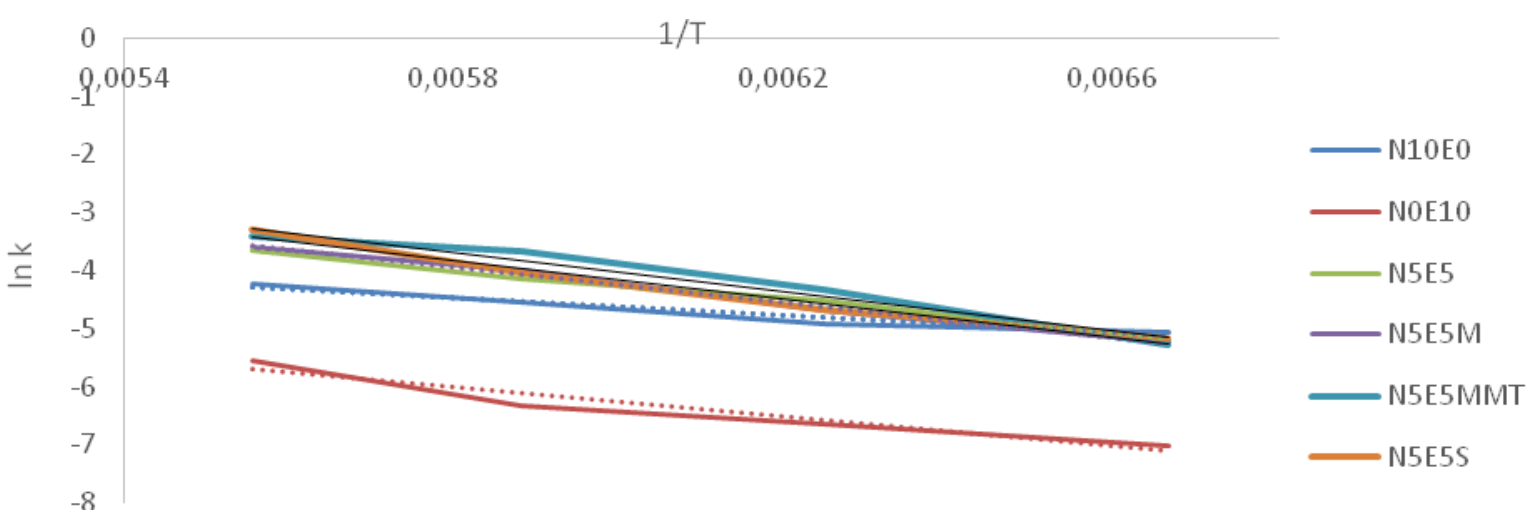

Gambar 2. Plot grafik persamaan (4) kompon NBR/EPDM

\begin{abstract}
Dari Tabel 5 diketahui bahwa montmorillonite menghasilkan energi aktivasi tertinggi pada campuran NBR/EPDM (14126.32 kJ/mol). Seluruh kompatibiliser membutuhkan energi yang lebih tinggi untuk proses vulkanisasi dibandingkan dengan NBR/EPDM tanpa kompatibiliser maupun kompon NBR dan kompon EPDM. Kompon dengan montmorillonite membutuhkan energi
\end{abstract}

aktivasi yang tertinggi untuk memulai reaksi vulkanisasi Energi aktivasi vulkanisasi adalah energi yang dibutuhkan selama proses pematangan. Energi aktivasi untuk campuran NBR/EPDM lebih besar daripada kompon NBR dan kompon EPDM dapat dikarenakan energi untuk pencampuran dua karet lebih besar daripada energi untuk memproses satu jenis karet. 
Tabel 5. Kinetika vulkanisasi NBR/EPDM

\begin{tabular}{|c|c|c|c|c|c|c|}
\hline \multirow{2}{*}{ Vulkanisat } & \multicolumn{4}{|c|}{ Rate konstan, $k\left(\mathrm{sec}^{-1}\right)$} & \multirow{2}{*}{$E a(\mathrm{~kJ} / \mathrm{mol})$} & \multirow{2}{*}{$\mathrm{R}^{2}$} \\
\hline & $150^{\circ} \mathrm{C}$ & $160^{\circ} \mathrm{C}$ & $170^{\circ} \mathrm{C}$ & $180^{\circ} \mathrm{C}$ & & \\
\hline $\mathrm{N}_{10} \mathrm{E}_{0}$ & 0.0064 & 0.0072 & 0.0106 & 0.0147 & 6395.38 & 0.9420 \\
\hline $\mathrm{N}_{0} \mathrm{E}_{10}$ & 0.0009 & 0.0013 & 0.0018 & 0.0039 & 10473.98 & 0.9325 \\
\hline $\mathrm{N}_{5} \mathrm{E}_{5}$ & 0.0055 & 0.0108 & 0.0158 & 0.0260 & 11340.30 & 0.9932 \\
\hline $\mathrm{N}_{5} \mathrm{E}_{5} \mathrm{M}$ & 0.0053 & 0.0093 & 0.0185 & 0.0277 & 12693.82 & 0.9944 \\
\hline $\mathrm{N}_{5} \mathrm{E}_{5} \mathrm{MMT}$ & 0.0051 & 0.0133 & 0.0252 & 0.0328 & 14126.32 & 0.9640 \\
\hline $\mathrm{N}_{5} \mathrm{E}_{5} \mathrm{~S}$ & 0.0057 & 0.0094 & 0.0173 & 0.0367 & 13812.05 & 0.9792 \\
\hline
\end{tabular}

\section{KESIMPULAN}

Dari penelitian yang telah dilakukan, diketahui bahwa campuran NBR/EPDM memberikan kemampuan proses kompon dan karakteristik vulkanisat yang lebih baik dibandingkan dengan kompon NBR dan kompon EPDM secara terpisah berdasarkan mooney viscosity (14.455 MU), waktu optimum (948; 444.5; 249.5; 129.5 detik pada $150,160,170$, dan $\left.180^{\circ} \mathrm{C}\right)$ serta indeks kecepatan pematangan $(0.113 ; 0.233 ; 0.440 ; 0.893$ detik $^{-1}$ pada $150,160,170$, dan $180^{\circ} \mathrm{C}$ ). Kompatibiliser tidak memberi pengaruh yang sangat signifikan terhadap waktu scorch dan selisih torsi kompon. Kompatibiliser montmorillonite memberikan kemampuan proses kompon terbaik dengan viskositas mooney terendah (11.735 MU), waktu pemasakan optimum yang baik $(1059.5 ; 434.5 ; 263$; 128 detik pada $150,160,170$, dan $180^{\circ} \mathrm{C}$ ) serta indeks kecepatan pematangan tertinggi $\left(0.100 ; 0.234 ; 0.422 ; 0.901\right.$ detik $^{-1}$ pada $150,160,170$, dan $\left.180^{\circ} \mathrm{C}\right)$. Kompon dengan montmorillonite sebagai kompatibiliser membutuhkan energi aktivasi tertinggi untuk memulai reaksi vulkanisasi $(14126.32 \mathrm{~kJ} / \mathrm{mol})$. Hal ini menunjukkan bahwa montmorillonite dapat menjadi kompatibiliser yang sesuai untuk campuran NBR/EPDM.

\section{UCAPAN TERIMAKASIH}

Penulis mengucapkan terimakasih kepada Balai Besar Kulit, Karet, dan
Plastik atas pendanaan dari penelitian ini. Penulis juga mengucapkan terimakasih kepada Ir. Arum Yuniari yang telah memberi masukan dalam kegiatan ini.

\section{DAFTAR PUSTAKA}

Al-gahtani, S. (2011). Mechanical Properties of Acrylonitrile butadiene / Ethylene Propylene Diene Monomer Blends: Effects of Blend Ratio and Filler Addition. Journal of American Science.7(8): 804809.

Arayapranee, W., \& Rempel, G. L. (2007). Properties of NR / EPDM Blends with or without Methyl Methacrylate-ButadieneStyrene ( MBS ) as a Compatibilizer. International Journal of Materials and Structural Reliability.5(1): 1-12.

Indrajati, I. N., \& Sholeh, M. (2014). Pengaruh rasio MBTS/ZDEC pada campuran karet alam dan etilen propilen diena yang dibuat dengan teknik kontrol migrasi curatives. Majalah Kulit, Karet Dan Plastik. 30(1): 43-52.

Jovanovic, S., Markovic, G., Budinski, J., \& Marinovic, M. (2013). Composites based on carbon black reinforced NBR / EPDM rubber blends Composites: Part B. Composites: Part B.45: 333-340. http://doi.org/10.1016/j.compositesb.2012 .05 .020

Jovanović, V., Budinski-Simendić, J., Samardžija-Jovanović, S., Marković, G., \& Marinović-Cincović, M. (2009). The influence of carbon black on curing kinetics and thermal aging of acrylonitrile-butadiene rubber. Chemical Industry and Chemical Engineering Quarterly.15(4): 283-289. http://doi.org/10.2298/CICEQ0904283J 
Kantala, C., Wimolmala, E., Sirisinha, C., \& Sombatsompop, N. (2009). Reinforcement of compatibilized NR / NBR blends by fly ash particles and precipitated silica. Polymer Advance Technology.20: 448-458. http://doi.org/10.1002/pat.1293

Kinasih, N. A., \& Fathurrohman, M. I. (2016). Ketahanan n-pentana dan sifat mekanis vulkanisat karet perapat dari campuran karet alam / akrilonitril-butadiena dengan kompatibiliser. Majalah Kulit, Karet Dan Plastik.32(2), 99-110.

Liu, Y., Li, H., Ding, X., Zhu, J., Zhang, L., Pan, W., \& Cai, R. (2014). Effect of the compatibilizers on polycarbonate ( PC ) ( ABS ) blend.1(3): 48-52.

Mayasari, H. E., Setyadewi, N. M., \& Yuniari, A. (2017). Pengaruh Kompatibiliser pada Karakteristik Kompon dan Sifat Mekanik Komposit NBR / EPDM Influence of Compatibilizer on Compound Characteristic and Mechanical Properties of NBR / EPDM Composite. Prosiding Seminar Nasional Kulit, Karet, Dan Plastik.6: 111-122.

Moolsin, S., \& Saksayamkul, N. (2016). Natural rubber grafted poly ( methyl methacrylate ) as compatibilizer in 50 / 50 natural rubber / nitrile rubber blend. Journal of Elastomer \& Plastics. 1-18. http://doi.org/10.1177/009524431667102 1

Mousavi, S. R., \& Amraei, I. A. (2015). Influence of nanosilica and methyl methacrylate - butadiene - styrene core - shell rubber particles on the physicalmechanical properties and cure kinetics of diglycidyl ether of bisphenol-A-based epoxy resin. High Performance Polymers. 1-11. http://doi.org/10.1177/095400831560022 8

Nabil, H., Ismail, H., \& Azura, A. R. (2013). Compounding, mechanical and morphological properties of carbonblack-filled natural rubber/recycled ethylene-propylene-diene-monomer
(NR/R-EPDM)
blends
Polymer

Testing.32(2):

385-393 http://doi.org/10.1016/j.polymertesting.20 12.11.003

Ning, N., Ma, Q., Zhang, Y., Zhang, L., \& Wu, H. (2014). Enhanced thermo-oxidative aging resistance of EPDM at high temperature by using synergistic antioxidants. Polymer Degradation and
Stability.102: 1-8. http://doi.org/10.1016/j.polymdegradstab. 2014.01.037

Rajasekar, R., Pal, K., Heinrich, G., Das, A., \& Das, C. K. (2009). Development of nitrile butadiene rubber - nanoclay composites with epoxidized natural rubber as compatibilizer. Materials and Design.30(9): 3839-3845. http://doi.org/10.1016/j.matdes.2009.03.0 14

Ren, L., Zhang, M. Y., Wang, Y. R., Na, H., \& Zhang, H. X. (2014). The influence of the arrangement of styrene in methyl methacrylate / butadiene / styrene on the properties of PMMA / SAN / MBS blends. Polymers Advance Technology.25: 273278. http://doi.org/10.1002/pat.3232

Samarz, S., Budinski-simendic, J., Markovic, G., \& Marinovic, M. (2013). Composites: Part B Composites based on carbon black reinforced NBR / EPDM rubber blends. Journal Composites.45: 333340.

http://doi.org/10.1016/j.compositesb.2012 .05 .020

Semsarzadeh, M. A., Bakhshandeh, G. R., \& Barvarz, M. G. (2005). Effect of carbon black on rate constant and activation energy of vulcanization in EPDM/BR and EPDM/NR blends. Iranian Polymer Journal. 14: 573-578.

Tawfik, M. E., \& El, S. H. (2014). Compatibilization of NBR / SBR blends using amphiphilic montmorillonites Journal of Elastomers. Journal of Elastomers and Plastics.46(6): 514-526. http://doi.org/10.1177/009524431347650 7

Vijayalekshmi, V., \& M, A. M. S. S. (2013). Mechanical , Thermal and Electrical Properties of EPDM / Silicone blend Nanocomposites. International Journal of Engineering Research and Applications.3(2): 1177-1180.

Yi, Z., Jincheng, W., Youcheng, D., Chen, P., \& Wen, Z. (2014). Enhanced Application Properties of EPDM / Montmorillonite Composites. Polymer \& Polymer Composites.22(9): 799-808.

Yuniari, A., Mayasari, H. E., \& Setyorini, I. (2017). Curing characteristics, swelling , and mechanical properties of natural rubber / nitrile butadiene rubber blends with and without compatibilizer.33(2): 65-72. 
Yuniari, A., Setyorini, I., \& Mayasari, H. E. (2016). Kinetika vulkanisasi dan sifat mekanis komposit acrylonitrile butadiene rubber ( NBR ). Majalah Kulit, Karet Dan Plastik. 32(2): 117-124.

Zhou, C., Liu, H., Chen, M., Wu, G., \& Zhang, $H$. (2012). Toughening of Polyvinylchloride by Methyl Methacrylate - Butadiene - Styrene Core - Shell Rubber Particles: Influence of Rubber Particle Size. Polymer Engineering and Science. 52(12): 2523-2529. http://doi.org/10.1002/pen 